\title{
Hyaluronan synthase 1: a mysterious enzyme with unexpected functions
}

\section{Hanna Siiskonen ${ }^{1}$, Sanna Oikari ${ }^{2}$, Sanna Pasonen-Seppänen ${ }^{2}$ and Kirsi Rilla ${ }^{2}$}

1 Department of Dermatology, Kuopio University Hospital, University of Eastern Finland, Kuopio, Finland

2 Institute of Biomedicine, University of Eastern Finland, Kuopio, Finland

\section{Edited by:}

David Naor, Hebrew University of

Jerusalem, Israel

Reviewed by:

Alberto Passi, Università degli Studi dell'Insubria, Italy

Timothy Bowen, Cardiff University, UK

*Correspondence:

Kirsi Rilla, Institute of Biomedicine

University of Eastern Finland,

Yliopistonranta 1 E, Kuopio 70211,

Finland

e-mail:kirsi.rilla@uef.fi
Hyaluronan synthase 1 (HAS1) is one of three isoenzymes responsible for cellular hyaluronan synthesis. Interest in HAS1 has been limited because its role in hyaluronan production seems to be insignificant compared to the two other isoenzymes, HAS2 and HAS3, which have higher enzymatic activity. Furthermore, in most cell types studied so far, the expression of its gene is low and the enzyme requires high concentrations of sugar precursors for hyaluronan synthesis, even when overexpressed in cell cultures. Both expression and activity of HAS1 are induced by pro-inflammatory factors like interleukins and cytokines, suggesting its involvement in inflammatory conditions. Has 1 is upregulated in states associated with inflammation, like atherosclerosis, osteoarthritis, and infectious lung disease. In addition, both full length and splice variants of HAS1 are expressed in malignancies like bladder and prostate cancers, multiple myeloma, and malignant mesothelioma. Interestingly, immunostainings of tissue sections have demonstrated the role of HAS1 as a poor predictor in breast cancer, and is correlated with high relapse rate and short overall survival. Utilization of fluorescently tagged proteins has revealed the intracellular distribution pattern of HAS1, distinct from other isoenzymes. In all cell types studied so far, a high proportion of HAS1 is accumulated intracellularly, with a faint signal detected on the plasma membrane and its protrusions. Furthermore, the pericellular hyaluronan coat produced by HAS1 is usually thin without induction by inflammatory agents or glycemic stress and depends on CD44-HA interactions. These specific interactions regulate the organization of hyaluronan into a leukocyte recruiting matrix during inflammatory responses. Despite the apparently minor enzymatic activity of HAS1 under normal conditions, it may be an important factor under conditions associated with glycemic stress like metabolic syndrome, inflammation, and cancer.

Keywords: hyaluronan, hyaluronan synthase, CD44, inflammation, cytokines, cancer

\section{INTRODUCTION}

Hyaluronan is the most abundant matrix polysaccharide, which maintains tissue homeostasis, gives compressive strength for tissues, acts as an ideal lubricant in body fluids and accelerates growth and healing. In addition, excess hyaluronan promotes cancer progression and mediates inflammation. Therefore, membranebound hyaluronan synthases (HAS1-3), special enzymes responsible for hyaluronan production, have a key role in regulation of these conditions. Despite highly homologous amino acid sequences, HAS's differ in subcellular localization, enzymatic activity, and regulation (1).

Despite almost 20 years of active research to sequence hyaluronan synthase genes, it is not known why vertebrates have three different isoforms of these enzymes, which are coded by separate genes on different chromosomes, to synthesize a single sugar polymer. Most research has focused on HAS2 and HAS3, while HAS1 has received the least attention and remains the most enigmatic, with only a few published reports of its biological effects on cellular behavior or association with disease states.

Knocking out the activity of hyaluronan synthase genes has provided a better understanding about normal HAS function.
Knockout of Has2 results in embryonic lethality with severe cardiac and vascular malformations (2), while the knockout of Has 1 or Has 3 does not have any apparent phenotype under non-stressed conditions $(3,4)$. However, double knockout of Has1 and Has3 leads to enhanced inflammation and accelerated wound closure of mouse skin (5), suggesting that they are necessary for the regulation of acute inflammation following injury.

A number of recent studies have highlighted the role of HAS1 in health and disease. Interestingly, Has1 was the most upregulated gene in aneuploid mouse embryonic fibroblasts (MEFs) with malignant properties (6) and splice variants of HAS1 are suggested to contribute to genetic instability (7), suggesting that it is susceptible to genetic alterations during oncogenic transformation. Surprisingly, HAS1 immunostainings of breast carcinoma cells correlated with hyaluronan staining, estrogen receptor negativity, HER2 positivity, high relapse rate, and short overall survival. In stromal cells of tumors from the same patients, the staining level of HAS1 was related to obesity and large tumor size (8). Human mesenchymal stem cells from different donors express HAS1 in variable but significant levels (9), suggesting its contribution to formation of a hyaluronan niche that maintains stemness of the 
cells. HAS1 is upregulated during human keratinocyte differentiation (10) and its expression correlates with levels of HA synthesis, indicating that HAS1 is an important regulator of skin homeostasis. Furthermore, as compared to other isoforms, differences in HAS1 substrate requirements (11-13), subcellular localization, and the structure of the hyaluronan coat $(7,13,14)$ have been reported, suggesting an independent role of HAS1 in the regulation of cell and tissue homeostasis. However, a comprehensive review of HAS1 has not been published. Therefore, the purpose of this review is to summarize and discuss the current knowledge of this mysterious enzyme. In this review, the abbreviations Has 1 and Has1 are used for non-human gene and protein, and HAS1 and HAS1 for human gene and protein, respectively.

\section{GENETICS AND FUNCTION OF Has1 GENES AND PROTEINS}

Hyaluronan is synthesized by HAS enzymes found in vertebrates, some bacteria, and a virus (15). The first Has was cloned in Group A Streptococcus pyogenes and it was predicted to be an integral membrane protein (16). The first human HAS gene was isolated by two research groups almost simultaneously. Shyjan and coworkers used functional expression cloning in Chinese hamster ovary (CHO)-cells (17) and Itano and Kimata screened cDNA libraries of human fetal brain (18).

Mammalian cells have three distinct synthase genes, Has 1-3 (the human genes are abbreviated here as HAS1-3). They are wellconserved with highly homologous amino acid sequences, but located on separate chromosomes. In humans, HAS1 resides in chromosome 19 at q13.3-13.4, HAS2 is located in chromosome 8 at q24.12 and HAS3 is in chromosome 16 at q22.1 (19). HAS1 gene has five exons, whereas HAS2 and HAS3 both have four (20). Several alternative splice variants of HAS1 have been reported in Waldenström's macroglobulinemia (21), multiple myeloma (22), and bladder cancer (23). In silico, the HAS1 gene has 46 possible transcription-factor binding sites $500 \mathrm{bp}$ upstream of the transcription start site (20).

Has1 is not essential for embryogenesis. Has2 knockout mice die at embryonic day 9.5 due to cardiovascular defects (2), but mice deficient in Has1 (3) or Has3 (4) are viable and fertile. Furthermore, double knockout Hasl and Has3 mice have been developed and are phenotypically normal (5).

The three hyaluronan synthase proteins in humans are designated as HAS1, HAS2, and HAS3. Mammalian hyaluronan synthases are integral membrane proteins with 4-6 transmembrane domains in addition to 1-2 membrane-associated domains $(15,24)$. The synthase enzymes need $\mathrm{Mg}^{2+}$ or $\mathrm{Mn}^{2+}$ to produce hyaluronan, in addition to the uridine diphosphate (UDP) sugar precursors, UDP-glucuronic acid (UDP-GlcUA), and UDP-Nacetylglucosamine (UDP-GlcNAc) $(15,25)$ The synthesis takes place at the inner surface of the plasma membrane utilizing cytoplasmic precursors (26). Human and mouse enzymes add the precursor sugars to the reducing end of the growing polymer (2729), while amphibian Xenopus laevis Has utilizes the non-reducing end (30), like the Pasteurella multocida hyaluronan synthase (31).

It has been suggested that the HAS enzymes do not require any primers for the synthesis of hyaluronan (32). The adenosine triphosphate-binding cassette (ABC) transporters have been proposed to be important for hyaluronan translocation on the plasma membrane of fibroblasts (33), requiring a concurrent efflux of $\mathrm{K}^{+}$ions (34). However, ABC transporters do not seem to contribute to the translocation of hyaluronan in breast cancer cells (35). The Has protein has been shown to produce hyaluronan in a combined process of synthesis and membrane translocation, as demonstrated by Has reconstituted into proteoliposomes in Streptococcus equisimilis (Se) (36). In addition, there is an intraprotein pore in Has and the synthase itself is able to translocate hyaluronan in liposomes containing purified Se-Has (37).

\section{REGULATION OF HAS1 EXPRESSION AND ACTIVITY}

The three HAS genes are often regulated in parallel $(38,39)$ and the synthesis of hyaluronan reflects changes at the mRNA level (40-44). HAS1 expression is transcriptionally regulated by transforming growth factor- $\beta$ (TGF- $\beta$ ) in synoviocytes $(45,46)$ and by the pro-inflammatory cytokine interleukin- $1 \beta$ (IL-1 $\beta$ ) in fibroblasts $(44,47,48)$, while these factors may have similar or opposite effects on other HASs, depending on cell type. The nuclear factor kappa B (NF-кB) (49) and tyrosine kinases (50) have been shown to be important for IL-1 $\beta$-induced HAS1 activation, while induction of HAS1 by TGF- $\beta$ seems to act through the p38 MAPK pathway (51). There is evidence that some of the effects are mediated by transcription-factors sp1 (52) and sp3 (53). Table 1 summarizes the growth factors and cytokines that regulate Has1/HAS1 expression. In addition to these factors, ultraviolet $\mathrm{B}$ radiation induces a fast up-regulation of Has1 expression in rat epidermal

Table 1 | Transcriptional regulation of Has $1 /$ HAS1 by different growth factors and cytokines ( $\uparrow$ increased, $\downarrow$ decreased)

\begin{tabular}{llll}
\hline Agent & Cell/tissue & HAS1 & Reference \\
\hline EGF & Human fibroblast & $\uparrow$ & $(44)$ \\
EGF & Human oral mucosal cell & $\uparrow$ & $(44)$ \\
FGF2 & Human dental pulp & $\uparrow$ & $(58)$ \\
FGF2 & Human periodontal ligament & $\uparrow$ & $(59)$ \\
FGF & Human fibroblast & $\uparrow$ & $(60)$ \\
Forskolin & Human orbital fibroblast & $\uparrow$ & $(48)$ \\
IGF & Human fibroblast & $\uparrow$ & $(60)$ \\
IL-1 $\beta$ & Human fibroblast & $\uparrow$ & $(44)$ \\
IL-1 $\beta$ & Human fibroblast & $\uparrow$ & $(61)$ \\
IL-1 $\beta$ & Murine uterine fibroblast & $\uparrow$ & $(47)$ \\
IL-1 $\beta$ & Human orbital fibroblast & $\uparrow$ & $(48)$ \\
IL-1 $\beta$ & Human dermal fibroblast & $\uparrow$ & $(53)$ \\
PDGF & Human fibroblast & $\uparrow$ & $(62)$ \\
Progesterone & Murine uterine fibroblast & $\downarrow$ & $(47)$ \\
Prostaglandin D2 & Human orbital fibroblast & $\uparrow$ & $(63)$ \\
Prostaglandin E2 & Human synoviocyte & $\uparrow$ & $164)$ \\
TGF- $\beta$ & Human fibroblast & $\uparrow$ & $(65)$ \\
TGF- $\beta$ & Human keratinocyte & $\uparrow$ & $(65)$ \\
TGF- $\beta$ & Human synoviocyte & $\uparrow$ & $(46)$ \\
TGF- $\beta$ & Human synoviocyte & $\uparrow$ & $(45)$ \\
TGF- $\beta$ & Human dermal fibroblast & $\uparrow$ & $(63)$ \\
Estradiol & Human vascular smooth muscle cell & $\downarrow$ & $(67)$ \\
4-MU & Human synoviocyte & $\uparrow$ & \\
TGF- $\beta 1$ & TGF- $\beta$ & $\uparrow$ & $\uparrow$
\end{tabular}


keratinocytes (54). Additionally, Has1 expression levels are raised in renal (55) and pulmonary (56) ischemia and hyperglycemia (57). The synthesis of hyaluronan by HAS1 is also regulated by the substrate concentrations of the precursor sugars (discussed in detail later in this review).

There is evidence that the activities of HAS2 and HAS3 are regulated by posttranslational modifications like phosphorylation $(38,69)$, ubiquitination (70), or O-GlcNAcylation (71). Whether these modifications are involved in the regulation of HAS1 activity is not completely known. Phosphorylation seems not to regulate HAS1 activation (72), but HAS1 can exist in multimers of full length-HAS1 or its variants, formed by intermolecular disulfide bonds (73).

The reported length of hyaluronan polymers produced by each of the mammalian Has differs, but the obtained results vary depending on the experimental set-up (74-77). For example, in membrane preparations from $\mathrm{CHO}$-cells transfected with recombinant Has isoforms, Has 2 produced the largest hyaluronan (over $\left.3.9 \times 10^{6} \mathrm{Da}\right)$, Has 3 produced intermediate length hyaluronan $\left(0.12-1 \times 10^{6} \mathrm{Da}\right)$, and HAS1 produced the smallest polymer $\left(0.12 \times 10^{6} \mathrm{Da}\right)$. However, all isoforms produced high molecular weight hyaluronan $\left(3.9 \times 10^{6} \mathrm{Da}\right)$ in live cells $(76)$. The size of the growing hyaluronan chain is increased or decreased by mutation of certain cysteine or serine amino acids in the Has1 protein in $X$. laevis, suggesting that the size of the hyaluronan chain is affected by the ability of the synthase to bind it (74).

\section{SUBCELLULAR LOCALIZATION AND TRAFFIC OF HAS1 AND ITS IMPACT ON FORMATION OF HA-COAT}

Our understanding of the localization and traffic of Has proteins has been deepened after recruitment of fluorescent HAS fusion proteins together with live cell imaging (78-80). All studies reported so far suggest that like other Has/HAS isoforms, Has1 follows the normal intracellular route from rER to Golgi (78), and its traffic is regulated similarly to other HAS isoforms (13), as shown by manipulation of its traffic in live cells by factors like 4-MU and brefeldin A (BFA).

A typical subcellular localization pattern of GFP-HAS1 is presented in Figure 1. The GFP-HAS1 signal is mainly cytoplasmic, rather than on the plasma membrane, being distributed either diffusely or in cytoplasmic patches, and partially co-localizing with the Golgi apparatus $(13,14,73)$. Only a small proportion of the total cellular pool of HAS1 is located on the plasma membrane, even when activated with glucosamine (12), or inflammatory cytokines like TNF- $\alpha$ or IL-1 $\beta$ (13). Occasionally, HAS1 signal is seen on or near the plasma membrane, usually as patches or concentrated spots (arrows in Figure 1), or on the plasma membrane protrusions $(13,14)$. The low plasma membrane signal of HAS1 is in parallel with the low activity level of HAS1, because latent HAS enzymes are thought to stay in the ER-Golgi compartment.

In addition to the full-length form, HAS1 has multiple transcript variants resulting from alternative splicing. Transfected HAS1V-GFP constructs localize with cytoskeletal structures like microtubules $(7,73)$. The reticular localization of the standard form of HAS1 (Figures 1 and 2) suggests that all forms of HAS1 studied so far are associated with the cytoskeletal network or endoplasmic reticulum, which is a distribution that is not typical for HAS2 or HAS3, and indicates different regulation and binding partners.

The size of the pericellular hyaluronan coat correlates with activity of hyaluronan synthesis. Interestingly, even high overexpression of HAS1 in cell types with little or no endogenous hyaluronan production is not enough to produce a clearly visible hyaluronan coat $(12,13,76)$. Furthermore, like previously published (12-14), the coat produced by HAS1 has a clearly different, more "cloudy" structure (Figures 1 and 2), as compared to the tight and concentrated coat around plasma membrane protrusions produced by HAS2, and especially HAS3 (Figure 2). However, the size of the coat produced by HAS1 can be induced upon induction by inflammatory agents or glucosamine $(12,13)$. The effect of
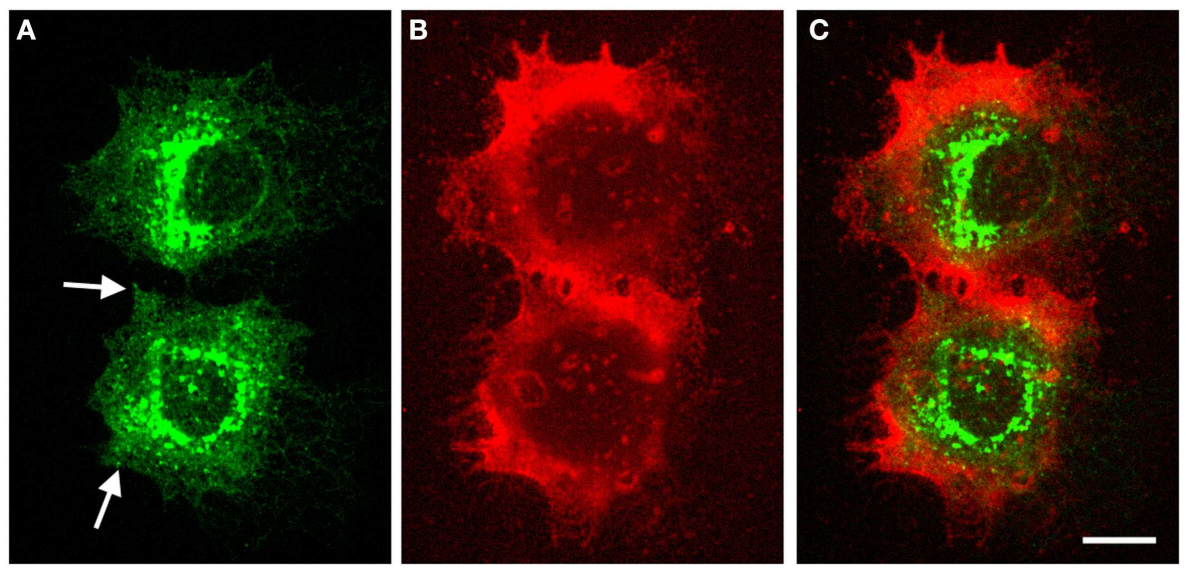

FIGURE 1 | Intracellular localization of GFP-HAS1 and structure of pericellular hyaluronan coat induced by GFP-HAS1 overexpression. Confocal optical sections of live MCF-7 breast cancer cells transfected with EGFP-HAS1 (green) and stained with $\mathrm{fHABC}$ to visualize the hyaluronan coat (red). Localization of EGFP-HAS1 is shown in (A), fHABC in (B), and merged images in (C). Arrows in (A) point patches of signal near the plasma membrane. Scale bar $10 \mu \mathrm{m}$. Original data published in Ref. (13). 

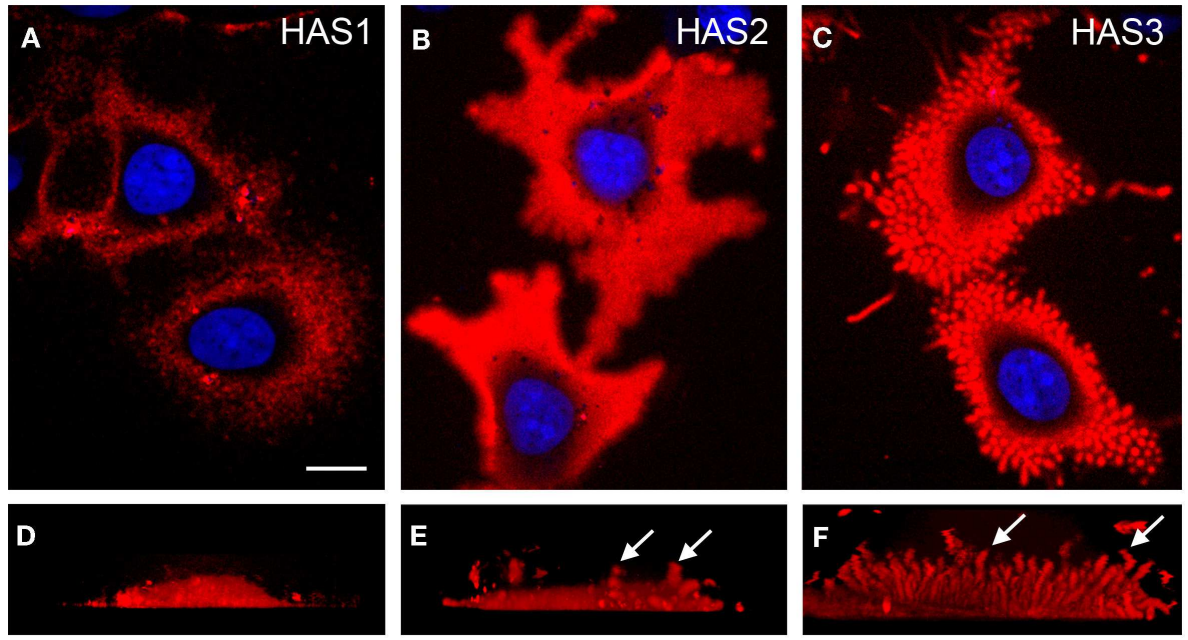

G

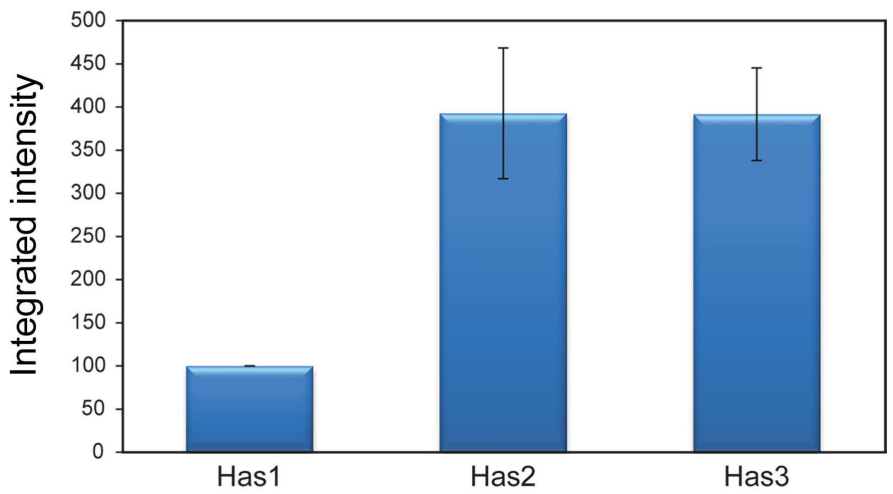

FIGURE 2 | Comparison of the structure and intensity of the pericellular hyaluronan coat in MCF-7 cells overexpressing the three HAS isoenzymes. Structure of the hyaluronan coat of live MCF-7 cells transfected with fusion proteins Dendra2-HAS1 (A,D), Dendra2-HAS2 (B,E), and Dendra2-HAS3 (C,F) and labeled with fHABC (red). Single confocal sections obtained from the middle level of nucleus (blue) are shown in (A-C). Vertical views created from compressed image stacks of horizontal optical sections are shown in (D-F) to show the dorsal protrusions (arrows). The integrated intensity (mean intensity $\times$ area) of hyaluronan coat probed with $\mathrm{fHABC}$ in the three HAS transfectants was measured in thresholded area of optical sections through the center of nucleus (G). Mean of three independent experiments is represented (total number of measured cells in each group $=92$ ). Magnification bar in (F), $10 \mu \mathrm{m}$. Original data published in Ref. $(12,81)$. glucosamine is presented in Figure 3. Additionally, the hyaluronan coat synthesized by HAS1 is largely dependent on hyaluronan interactions with CD44 (13).

Detailed studies on tissue distribution and subcellular localization of endogenous HAS's have been challenging due to the lack of reliable antibodies and apparently low expression level of HAS's in many cell types. Subcellular localization of endogenous HAS1 detected with affinity purified polyclonal antibodies shows a similar pattern to exogenously expressed HAS1 fusion proteins (14). HAS1 immunostainings have shown notable levels of HAS1 in mesothelial cells, fibroblasts (14), and human chondrosarcoma cells (9). Furthermore, MEFs have prominent Has1 staining (6). Examples of HAS1 immunostainings in cultured cells are summarized in Figure 4. These results are in line with the notable mRNA levels of Has1/HAS1 observed in these cell types $(6,12,13)$.

Staining patterns of HAS1 in tissue sections is in line with cell culture studies. Immunostainings of Hasl in developing tissues (14) and HAS1 in tumor tissues (8, 82-85), endometrium (86), and oral mucosa (87) have been published recently. In tumor tissues, HAS1 is typically expressed in tumor cells $(8,83-85)$, as well as in stromal fibroblasts (Figure 5). The localization of HAS1 is mainly intracellular, corresponding to the staining observed in cell cultures. Typical staining patterns vary from diffuse to granular with deposits next to the nucleus, which suggests HAS1 accumulation in the Golgi area (arrowheads in Figure 5), similar to that seen in cell cultures.

\section{HAS1 REQUIRES HIGH CELLULAR CONTENT OF UDP-SUGARS FOR ACTIVATION}

An important factor affecting activity of all HAS enzymes is the cytoplasmic availability of substrates, namely, UDP-GlcUA and UDP-GlcNAc. Many studies have shown that treatments influencing either UDP-GlcUA or UDP-GlcNAc levels regulate hyaluronan production [reviewed by Vigetti et al. (88)]. This role of substrates is particularly interesting in regulation of HAS1 as its activity of hyaluronan production in many cell models is low or absent unless stimulated. 

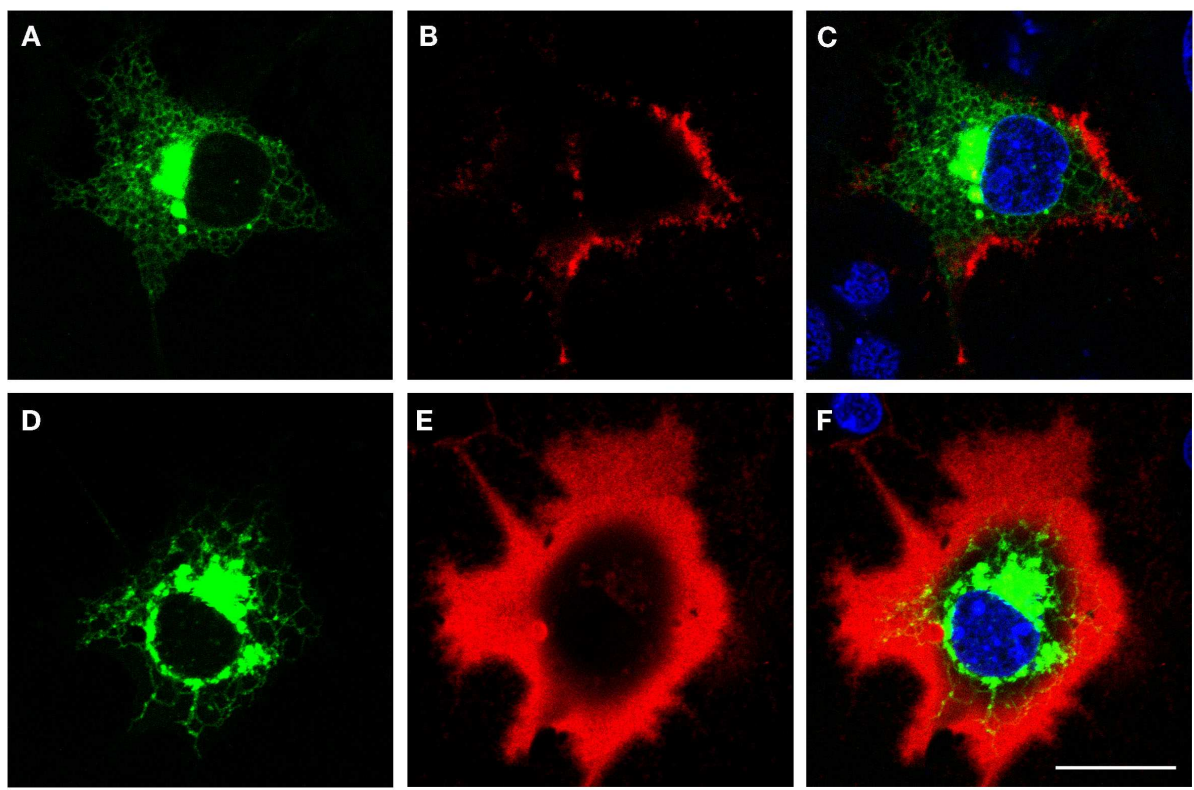

FIGURE 3 | Glucosamine induces the growth of hyaluronan coat produced by HAS1. Confocal optical sections of pericellular hyaluronan coats on COS-1 cells expressing Dendra2-HAS1 without glucosamine (A-C) and after $6 \mathrm{~h}$ incubation with $1 \mathrm{mM}$ glucosamine (D-F). Green, Dendra2-HAS1; red, hyaluronan coat; blue, nuclei. Magnification bars $20 \mu \mathrm{m}$. Original data published in Ref. $(12,13)$.

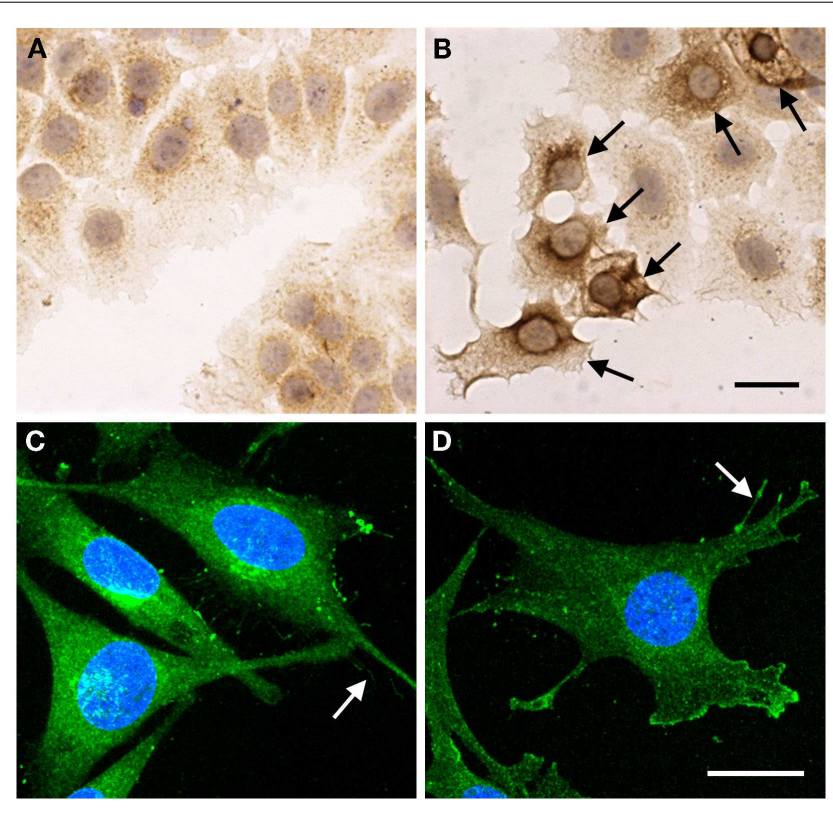

FIGURE 4 | Subcellular localization of endogenous HAS1 detected by immunostainings. MCF-7 cells transiently transfected with empty vector (A) and HAS1 expressing plasmid (B), followed by immunostaining with polyclonal HAS1 antibodies (brown color). Arrows in (B) show the HAS1 overexpressing cells. A 3D confocal projection of human chondrosarcoma cell (HCS) (C) and transformed mouse embryonic fibroblast (MEF) (D) stained with HAS1 immunofluorescence (green). Arrows in (C,D) point plasma membrane protrusions. Blue, nuclei. Magnification bars in (B,D) $=20 \mu \mathrm{m}$. Original data published in Ref. $(6,9,14)$.

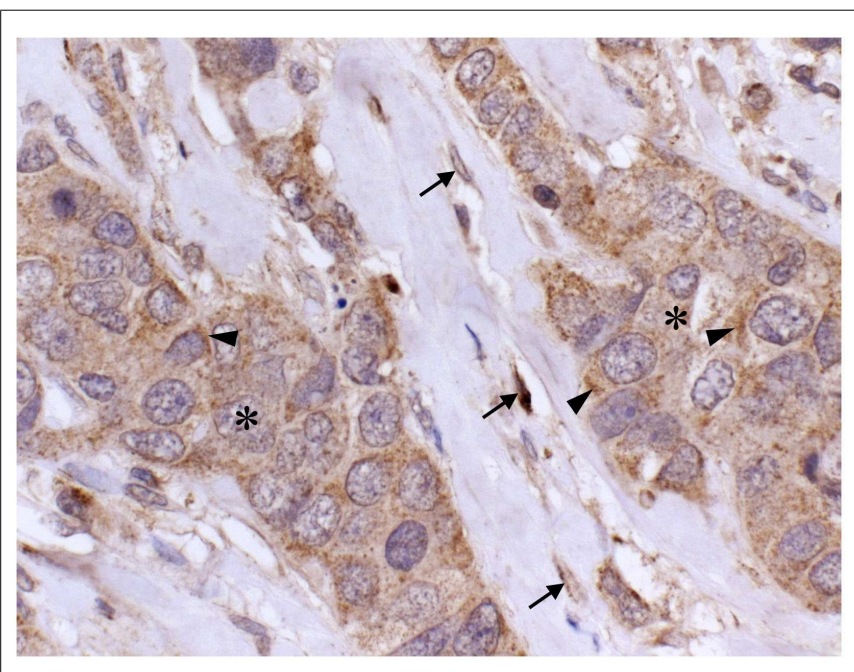

FIGURE 5 | Localization of HAS1 in breast cancer tissue. A paraffin section of breast carcinoma immunostained with HAS1 polyclonal antibody (brown). Nuclei are labeled blue. A mainly cytoplasmic localization of HAS1 is detected in carcinoma cells (asterisks) and in stromal fibroblasts (arrows). Special accumulation of staining is seen intracellularly (arrowheads). Magnification bar $50 \mu \mathrm{m}$. Original data published in Ref. (8).

In order to study the effect of UDP-GlcUA on hyaluronan production, 4-methylumbelliferone (4-MU) and overexpression of enzymes involved in either UDP-Glucose (UDPglucose pyrophosphorylase) or UDP-GlcUA (UDP-glucose 6-dehydrogenase) production have mainly been used $(39,89,90)$. 
These reports rely mostly on mRNA data to explain the altered hyaluronan production. The effect of UDP-GlcUA fluctuations on HAS1-3 expression levels vary considerably from one cell line to another and it is often impossible to reveal the exact role of HAS1 during these changes. A recent investigation demonstrated that availability of UDP-GlcUA can have a direct effect on HAS1 activity, as treatment of MCF-7 cells overexpressing HAS1 with an inducing agent and 4-MU significantly decrease hyaluronan coat compared to cells treated with the inducing agent only (13). It has been reported that Hasl has a lower affinity for UDP-GlcUA than other Has's, and the $K_{m}$ of Has1 is about double that of Has2-3. Interestingly, availability of the other substrate, UDP-GlcNAc, did not considerably influence the $K_{m}$ of Has1 toward UDP-GlcUA, whereas levels of UDP-GlcUA did have a significant effect of the $K_{m}$ toward UDP-GlcNAc (11).

The affinity of Has1 for UDP-GlcNAc is lower than the affinity of Has2-3 as with UDP-GlcUA. The $K_{m}$ toward UDP-GlcNAc of Has1 is about two to three times higher that of the other Has's. Interestingly, all Has enzymes exhibit lower affinity toward UDPGlcNAc than for UDP-GlcUA (11). Treatments with compounds like mannose and glucosamine that regulate UDP-GlcNAc content also affect cellular hyaluronan secretion levels $(12,91)$. Similar to the level of UDP-GlcUA, the availability of UDP-GlcNAc influences both mRNA levels and activity of all HAS's. The differences in substrate affinities are well demonstrated in intact cells using HAS1 overexpressing cell lines. Both COS-1 and MCF-7 cell lines have negligible endogenous hyaluronan production, and even overexpression of HAS1 enzymes does not cause prominent changes in it. Upon treatment with glucose or glucosamine, compounds that increase the amounts of hyaluronan substrates, the HAS1 enzyme is able to produce significant amounts of hyaluronan $(12,13)$. Furthermore, this effect of substrate availability on HAS1 activity is dose dependent (12).

The above mentioned findings on the regulation of HAS1 activity point out that although HAS1 has a minor role in total cellular hyaluronan production, it may have significant effects when induced by increased substrate availability. Since the affinity of HAS1 for its substrates is lower compared to the two other HAS's, the fluctuations in UDP-GlcNAc and UDP-GlcUA levels can have a more significant effect on HAS1 than on HAS2-3.

\section{HAS1 AS A MEDIATOR IN INFLAMMATION}

Many recent results suggest HAS1 may play a pivotal role during cell stress, such as inflammation. Earlier in this frontiers review series, Petrey and de la Motte comprehensively discussed the role of hyaluronan in inflammation (92). Whether hyaluronan acts as a pro- or anti-inflammatory molecule is highly dependent on its molecular size. Generally, low-molecular weight hyaluronan fragments mediate pro-inflammatory responses (93) such as recruitment of macrophages and other leukocytes to the injured or inflamed tissue $(94,95)$ and stimulate transcription of genes related to inflammation including several cytokines and matrix metalloproteinases (96). Growth factors and pro-inflammatory cytokines (Table 1) released during inflammation, like TGF- $\beta$, IL$1 \beta$, and TNF- $\alpha$, which stimulate inflammatory cells also induce expression of HAS1 $(44,45,64)$ and Has1 (97). Expression of HAS1 is also upregulated in response to prostaglandins $(98,99)$.
Therefore, Has1/HAS1 up-regulation has been noted in many diseases associated with inflammation such as murine atherosclerosis (100), human osteoarthritis (101), murine infectious lung disease (102), and human rheumatoid arthritis (45). HAS1 expression is also increased, among several other genes, in osteophytic chondrocytes (103). Interestingly, the expression of both HAS1 and HAS2 was reduced in the synovium of patients with osteoarthritis or rheumatoid arthritis compared to healthy controls (104). Moreover, elevated HAS1 expression is observed in oral lichen planus, which is a chronic inflammatory disease of the oral mucosa (87). It is worth noting that in oral lichen planus the increased HAS1 expression is detected in the basal layers of the epithelium, which is the most affected, inflamed area in lichen planus.

It is not known whether the product of HAS1 enzyme of certain polymer length, HAS1 enzyme itself or hyaluronan with HAS1 and hyaluronan binding proteins like CD44 mediate the proinflammatory responses. One explanation for HAS1 involvement in inflammation might be that HAS1 is associated with production of a special type of pericellular hyaluronan coat, which is proinflammatory. Recently, Siiskonen and co-workers showed that inflammatory agents and glycemic stress induce HAS1 to produce an expanded pericellular hyaluronan coat (13). Compared to Has3-induced hyaluronan coat, which is rather tight and formed around microvillus protrusions (105), HAS1 produces a looser, but extensive pericellular hyaluronan coat, which is dependent on CD44. In several cell types, these types of hyaluronan coats have been shown to associate with monocyte binding $(106,107)$. It has even shown that hyaluronan produced by Has1 binds mononuclear cells more effectively than hyaluronan produced by the two other Has enzymes (77). This could provide an explanation for the central role of HAS1 in inflammation.

In rheumatoid arthritis, the rate of hyaluronan synthesis is altered. Hyaluronan accumulates in joints affected by rheumatoid arthritis, which causes periarticular swelling and morning stiffness (108). In synoviocytes isolated from RA patients, HAS2 and HAS3 are constitutively activated, but HAS1 is the gene that responds readily to pro-inflammatory cytokines like IL-1 $\beta$ (49) and TGF$\beta$ (45). However, IL-1 $\beta$ is not able to stimulate Has 1 expression in healthy synoviocytes like in type-B synoviocytes isolated from rheumatoid arthritis patients $(49,109)$. This IL- $1 \beta$-induced HAS1 up-regulation is dependent on the activation of the transcriptionfactor NF- $\mathrm{B}$ (49), like many other pro-inflammatory molecules. In type- $\mathrm{B}$ synoviocytes, IL- $1 \beta$ stimulation induces the translocation of NF- $\kappa$ B into the nucleus, which results in up-regulation of HAS1 mRNA expression (49). Similarly, in fibroblast-like synoviocytes, viral infection causes NF-кB activation and increased HA release due to HAS1 up-regulation. This HAS1 up-regulation is reversed with mitogen-activated protein kinase p38 and JNK inhibitors indicating that viral RNA activates HAS1 through these signaling pathways (110). Moreover, HAS1 activation is blocked with commonly used anti-inflammatory drugs, hydrocortisone, and dexamethasone, in TGF- $\beta$ stimulated synoviocytes (51). In these cells, glucocorticoids block p38 activation, which results in suppressed HAS1 expression (51). Interestingly, sodium salicylate inhibits IL- $1 \beta$ induced HAS1 activation and HA release in type-B synoviocytes (64). This might explain some of the beneficial effects of sodium salicylate in the treatment of rheumatoid arthritis. 
In addition to its role in rheumatoid inflammation, altered HAS1 levels contribute to other inflammation-related states. In murine models of asthma, Has1 mRNA is increased at an early stage, but later decreased $(111,112)$. In thyroid dysfunction associated with activation of the thyrotropin receptor, hyaluronan is accumulated through up-regulation of HAS1 and HAS2 (113). Taken together, HAS1 seems to be fundamentally involved in the inflammatory processes. However, many questions are still waiting for an answer.

\section{HAS1 AS A PREDICTOR OF CANCER PROGRESSION}

Hyaluronan content is known to be increased in many cancers, which may be altered due to hyaluronan synthase expression. Few studies have shown a direct association of HAS's with cancer progression in vivo, but interestingly, HAS1 associates with tumor progression and prognostic factors in many cases. Increased expression of HAS1 is associated with poor patient survival in ovarian cancer $(114,115)$, colon cancer (116), Waldenström's macroglobulinemia (21), and multiple myeloma (22). In multiple myeloma and Waldenström's macroglobulinemia, the occurrence of HAS1 splice variants, rather than the full length HAS1, is related to cancer prognosis. HAS1 expression is also increased in bladder cancer, correlating with increased hyaluronan levels (23), and predicting metastasis (117). In bladder cancer, HAS1 has been shown to modulate HA and CD44 levels, affecting tumor growth and progression (118). Accumulation of hyaluronan is associated with poor patient survival in breast cancer $(119,120)$. Recently, HAS1 and HA stainings were found to correlate with each other in breast carcinoma cells of these tumors, and HAS1 was associated with estrogen receptor negativity, HER2 positivity, high relapse rate, and short overall survival. In addition, expression levels of stromal HAS1 and HAS2 were related to obesity, large tumor size, lymph node positivity, and estrogen receptor negativity (8).

In serous ovarian tumors, HAS1 has been shown to be very low or totally absent, whereas the levels of HAS2 and HAS3 mRNA or staining levels are not elevated compared to normal ovaries or benign tumors (83). Interestingly, the levels of HAS1 and HAS2 immunostainings are decreased in melanomas, correlating with reduced hyaluronan content and poor overall survival observed in these tumors $(85,121)$.

\section{CONCLUSION AND FUTURE CHALLENGES}

The hyaluronan coat produced by HAS1 differs from that of other isoenzymes, as shown by fluorescent hyaluronan binding probes. The flossy and loose coat is typical for cells with mesenchymal origin, like fibroblasts, mesothelial cells, synovial fibroblasts, and chondrocytes. Furthermore, as Table 1 summarizes, most of the cells that respond to cytokines or growth factors by upregulating Has1/HAS1 levels, are of the same mesenchymal origin. Additionally, these cell types secrete active proteoglycans and other molecules participating in hyaluronan coat formation, like versican, I $\alpha$, and TSG6, which are important players in inflammation (92) and are associated with hyaluronan cables detected in fixed cells. However, other HAS's are active in these cells, and cell types solely expressing HAS1 are not available, making it challenging to study the specific contribution of HAS1. The most specific method so far is the artificial overexpression of fluorescently tagged HAS1 in cells with low levels of HAS enzymes (12-14).

Interestingly, HAS1 overexpression in many epithelial cell types has shown a low activity in normal culture conditions, without addition of glucosamine or inflammatory cytokines. This suggests that these cell types may lack factors that are crucial for HAS1 activity. Several studies suggest that HAS1 has a low capacity to retain hyaluronan chains on the plasma membrane, thus other molecules may be required to retain hyaluronan chains on the plasma membrane and assemble the hyaluronan coat. A potential molecule for these interactions is CD44, which seems to play a special role in the formation of the HAS1-induced coat (13).

The complexity of hyaluronan metabolism, existence of three isoenzymes, and the crucial role of HAS2 make it complicated to study the biological effects of HAS1 in animal models. Furthermore, since most human tissues and cells express all HAS isoforms, it is impossible to get comprehensive answers and make conclusions on the role of a single isoenzyme. Furthermore, many cells and tissues express low or negligible levels of HAS1 mRNA. However, variable sensitivity of the methods used and other limitations may explain the low or absent HAS1 levels detected in some cases.

Several trials have been done to solve the function and regulation of this puzzling enzyme. Evidently, HAS1 is an important regulator during inflammation and in states with altered sugar metabolism. However, contradictory results raise several new questions, which need to be resolved before we can elucidate the exact role of HAS1.

\section{ACKNOWLEDGMENTS}

The authors gratefully acknowledge financial support from the Academy of Finland (grant 276426), Spearhead Funds from the University of Eastern Finland (Cancer Center of Eastern Finland), Saimaa Cancer Foundation, Cancer Foundation of Northern Savo, and the Special Government Funding of the Kuopio University Hospital.

\section{REFERENCES}

1. Tammi RH, Passi AG, Rilla K, Karousou E, Vigetti D, Makkonen K, et al. Transcriptional and post-translational regulation of hyaluronan synthesis. FEBS J (2011) 278(9):1419-28. doi:10.1111/j.1742-4658.2011.08070.x

2. Camenisch TD, Spicer AP, Brehm-Gibson T, Biesterfeldt J, Augustine ML, Calabro A Jr, et al. Disruption of hyaluronan synthase-2 abrogates normal cardiac morphogenesis and hyaluronan-mediated transformation of epithelium to mesenchyme. J Clin Invest (2000) 106(3):349-60. doi:10.1172/JCI10272

3. Kobayashi N, Miyoshi S, Mikami T, Koyama H, Kitazawa M, Takeoka M, et al. Hyaluronan deficiency in tumor stroma impairs macrophage trafficking and tumor neovascularization. Cancer Res (2010) 70(18):7073-83. doi:10.1158/0008-5472.CAN-09-4687

4. Bai KJ, Spicer AP, Mascarenhas MM, Yu L, Ochoa CD, Garg HG, et al. The role of hyaluronan synthase 3 in ventilator-induced lung injury. Am J Respir Crit Care Med (2005) 172(1):92-8. doi:10.1164/rccm.200405-652OC

5. Mack JA, Feldman RJ, Itano N, Kimata K, Lauer M, Hascall VC, et al. Enhanced inflammation and accelerated wound closure following tetraphorbol ester application or full-thickness wounding in mice lacking hyaluronan synthases Has1 and Has3. J Invest Dermatol (2012) 132(1):198-207. doi:10.1038/jid.2011.248

6. Högnäs G, Tuomi S, Veltel S, Mattila E, Murumagi A, Edgren H, et al. Cytokinesis failure due to derailed integrin traffic induces aneuploidy and oncogenic transformation in vitro and in vivo. Oncogene (2012) 31(31):3597-606. doi:10.1038/onc. 2011.527

7. Adamia S, Kriangkum J, Belch AR, Pilarski LM. Aberrant posttranscriptional processing of hyaluronan synthase 1 in malignant transformation and 
tumor progression. Adv Cancer Res (2014) 123:67-94. doi:10.1016/B978-012-800092-2.00003-4

8. Auvinen P, Rilla K, Tumelius R, Tammi M, Sironen R, Soini Y, et al. Hyaluronan synthases (HAS1-3) in stromal and malignant cells correlate with breast cancer grade and predict patient survival. Breast Cancer Res Treat (2014) 143(2):277-86. doi:10.1007/s10549-013-2804-7

9. Qu C, Rilla K, Tammi R, Tammi M, Kröger H, Lammi MJ. Extensive CD44dependent hyaluronan coats on human bone marrow-derived mesenchymal stem cells produced by hyaluronan synthases HAS1, HAS2 and HAS3. Int J Biochem Cell Biol (2014) 48C:45-54. doi:10.1016/j.biocel.2013.12.016

10. Malaisse J, Bourguignon V, De Vuyst E, Lambert de Rouvroit C, Nikkels AF, Flamion B, et al. Hyaluronan metabolism in human keratinocytes and atopic dermatitis skin is driven by a balance of hyaluronan synthases 1 and 3. J Invest Dermatol (2014) 134(8):2174-82. doi:10.1038/jid.2014.147

11. Itano N, Sawai T, Yoshida M, Lenas P, Yamada Y, Imagawa M, et al. Three isoforms of mammalian hyaluronan synthases have distinct enzymatic properties. J Biol Chem (1999) 274(35):25085-92. doi:10.1074/jbc.274.35.25085

12. Rilla K, Oikari S, Jokela TA, Hyttinen JM, Kärnä R, Tammi RH, et al. Hyaluronan synthase 1 (HAS1) requires higher cellular UDP-GlcNAc concentration than HAS2 and HAS3. J Biol Chem (2013) 288(8):5973-83. doi:10.1074/jbc. M112.443879

13. Siiskonen H, Kärnä R, Hyttinen JM, Tammi RH, Tammi MI, Rilla K. Hyaluronan synthase 1 (HAS1) produces a cytokine-and glucose-inducible, CD44dependent cell surface coat. Exp Cell Res (2014) 320(1):153-63. doi:10.1016/j. yexcr.2013.09.021

14. Törrönen K, Nikunen K, Kärnä R, Tammi M, Tammi R, Rilla K. Tissue distribution and subcellular localization of hyaluronan synthase isoenzymes. Histochem Cell Biol (2014) 141(1):17-31. doi:10.1007/s00418-013-1143-4

15. Weigel PH, DeAngelis PL. Hyaluronan synthases: a decade-plus of novel glycosyltransferases. J Biol Chem (2007) 282(51):36777-81. doi:10.1074/jbc. R700036200

16. DeAngelis PL, Papaconstantinou J, Weigel PH. Molecular cloning, identification, and sequence of the hyaluronan synthase gene from group A Streptococcus pyogenes. J Biol Chem (1993) 268(26):19181-4.

17. Shyjan AM, Heldin P, Butcher EC, Yoshino T, Briskin MJ. Functional cloning of the cDNA for a human hyaluronan synthase. J Biol Chem (1996) 271(38):23395-9. doi:10.1074/jbc.271.38.23395

18. Itano N, Kimata K. Molecular cloning of human hyaluronan synthase. Biochem Biophys Res Commun (1996) 222(3):816-20. doi:10.1006/bbrc.1996.0827

19. Spicer AP, Seldin MF, Olsen AS, Brown N, Wells DE, Doggett NA, et al. Chromosomal localization of the human and mouse hyaluronan synthase genes. Genomics (1997) 41(3):493-7. doi:10.1006/geno.1997.4696

20. Monslow J, Williams JD, Norton N, Guy CA, Price IK, Coleman SL, et al. The human hyaluronan synthase genes: genomic structures, proximal promoters and polymorphic microsatellite markers. Int J Biochem Cell Biol (2003) 35(8):1272-83. doi:10.1016/S1357-2725(03)00048-7

21. Adamia S, Crainie M, Kriangkum J, Mant MJ, Belch AR, Pilarski LM. Abnormal expression of hyaluronan synthases in patients with Waldenstrom's macroglobulimenia. Semin Oncol (2003) 30(2):165-8. doi:10.1053/sonc.2003.50042

22. Adamia S, Reiman T, Crainie M, Mant MJ, Belch AR, Pilarski LM. Intronic splicing of hyaluronan synthase 1 (HAS1): a biologically relevant indicator of poor outcome in multiple myeloma. Blood (2005) 105(12):4836-44. doi:10.1182/blood-2004-10-3825

23. Golshani R, Hautmann SH, Estrella V, Cohen BL, Kyle CC, Manoharan M, et al. HAS1 expression in bladder cancer and its relation to urinary HA test. Int J Cancer (2007) 120(8):1712-20. doi:10.1002/ijc.22222

24. Weigel PH, Hascall VC, Tammi M. Hyaluronan synthases. J Biol Chem (1997) 272(22):13997-4000. doi:10.1074/jbc.272.22.13997

25. Markovitz A, Cifonelli JA, Dorfman A. The biosynthesis of hyaluronic acid by group A Streptococcus. VI. Biosynthesis from uridine nucleotides in cell-free extracts. J Biol Chem (1959) 234:2343-50.

26. Prehm P. Hyaluronate is synthesized at plasma membranes. Biochem J (1984) 220(2):597-600.

27. Prehm P. Synthesis of hyaluronate in differentiated teratocarcinoma cells. Characterization of the synthase. Biochem J (1983) 211(1):181-9.

28. Asplund T, Brinck J, Suzuki M, Briskin MJ, Heldin P. Characterization of hyaluronan synthase from a human glioma cell line. Biochim Biophys Acta (1998) 1380(3):377-88. doi:10.1016/S0304-4165(98)00010-5
29. Prehm P. Biosynthesis of hyaluronan: direction of chain elongation. Biochem $J$ (2006) 398(3):469-73. doi:10.1042/BJ20060431

30. Bodevin-Authelet S, Kusche-Gullberg M, Pummill PE, DeAngelis PL, Lindahl U. Biosynthesis of hyaluronan: direction of chain elongation. J Biol Chem (2005) 280(10):8813-8. doi:10.1074/jbc.M412803200

31. DeAngelis PL. Molecular directionality of polysaccharide polymerization by the Pasteurella multocida hyaluronan synthase. J Biol Chem (1999) 274(37):26557-62. doi:10.1074/jbc.274.37.26557

32. Prehm P. Synthesis of hyaluronate in differentiated teratocarcinoma cells. Mechanism of chain growth. Biochem J (1983) 211(1):191-8.

33. Schulz T, Schumacher U, Prehm P. Hyaluronan export by the ABC transporter MRP5 and its modulation by intracellular cGMP. J Biol Chem (2007) 282(29):20999-1004. doi:10.1074/jbc.M700915200

34. Hagenfeld D, Borkenhagen B, Schulz T, Schillers H, Schumacher U, Prehm P. Hyaluronan export through plasma membranes depends on concurrent $\mathrm{K}+$ efflux by K(ir) channels. PLoS One (2012) 7(6):e39096. doi:10.1371/journal. pone.0039096

35. Thomas NK, Brown TJ. ABC transporters do not contribute to extracellular translocation of hyaluronan in human breast cancer in vitro. Exp Cell Res (2010) 316(7):1241-53. doi:10.1016/j.yexcr.2010.01.004

36. Hubbard C, McNamara JT, Azumaya C, Patel MS, Zimmer J. The hyaluronan synthase catalyzes the synthesis and membrane translocation of hyaluronan. J Mol Biol (2012) 418(1-2):21-31. doi:10.1016/j.jmb.2012.01.053

37. Medina AP, Lin J, Weigel PH. Hyaluronan synthase mediates dye translocation across liposomal membranes. BMC Biochem (2012) 13:2. doi:10.1186/14712091-13-2

38. Vigetti D, Genasetti A, Karousou E, Viola M, Clerici M, Bartolini B, et al. Modulation of hyaluronan synthase activity in cellular membrane fractions. J Biol Chem (2009) 284(44):30684-94. doi:10.1074/jbc.M109.040386

39. Kultti A, Pasonen-Seppänen S, Jauhiainen M, Rilla KJ, Kärnä R, Pyoriä E, et al. 4-Methylumbelliferone inhibits hyaluronan synthesis by depletion of cellular UDP-glucuronic acid and downregulation of hyaluronan synthase 2 and 3. Exp Cell Res (2009) 315:1914-23. doi:10.1016/j.yexcr.2009.03.002

40. Jacobson A, Brinck J, Briskin MJ, Spicer AP, Heldin P. Expression of human hyaluronan synthases in response to external stimuli. Biochem J (2000) $348(\mathrm{Pt}$ 1):29-35. doi:10.1042/0264-6021:3480029

41. Recklies AD, White C, Melching L, Roughley PJ. Differential regulation and expression of hyaluronan synthases in human articular chondrocytes, synovial cells and osteosarcoma cells. Biochem $J$ (2001) 354(Pt 1):17-24. doi:10.1042/0264-6021:3540017

42. Pienimäki JP, Rilla K, Fülop C, Sironen RK, Karvinen S, Pasonen S, et al. Epidermal growth factor activates hyaluronan synthase 2 in epidermal keratinocytes and increases pericellular and intracellular hyaluronan. J Biol Chem (2001) 276(23):20428-35. doi:10.1074/jbc.M007601200

43. Karvinen S, Pasonen-Seppänen S, Hyttinen JM, Pienimäki JP, Törrönen K, Jokela TA, et al. Keratinocyte growth factor stimulates migration and hyaluronan synthesis in the epidermis by activation of keratinocyte hyaluronan synthases 2 and 3. J Biol Chem (2003) 278(49):49495-504. doi:10.1074/jbc. M310445200

44. Yamada Y, Itano N, Hata K, Ueda M, Kimata K. Differential regulation by IL-1beta and EGF of expression of three different hyaluronan synthases in oral mucosal epithelial cells and fibroblasts and dermal fibroblasts: quantitative analysis using real-time RT-PCR. J Invest Dermatol (2004) 122(3):631-9. doi:10.1111/j.0022-202X.2004.22332.x

45. Stuhlmeier KM, Pollaschek C. Differential effect of transforming growth factor beta (TGF-beta) on the genes encoding hyaluronan synthases and utilization of the p38 MAPK pathway in TGF-beta-induced hyaluronan synthase 1 activation. J Biol Chem (2004) 279(10):8753-60. doi:10.1074/jbc.M303945200

46. Oguchi T, Ishiguro N. Differential stimulation of three forms of hyaluronan synthase by TGF-beta, IL-1beta, and TNF-alpha. Connect Tissue Res (2004) 45(4-5):197-205. doi:10.1080/03008200490523031

47. Uchiyama T, Sakuta T, Kanayama T. Regulation of hyaluronan synthases in mouse uterine cervix. Biochem Biophys Res Commun (2005) 327(3):927-32. doi:10.1016/j.bbrc.2004.12.092

48. van Zeijl CJ, Fliers E, van Koppen CJ, Surovtseva OV, de Gooyer ME, Mourits MP, et al. Effects of thyrotropin and thyrotropin-receptor-stimulating Graves' disease immunoglobulin G on cyclic adenosine monophosphate and hyaluronan production in nondifferentiated orbital fibroblasts of 
Graves' ophthalmopathy patients. Thyroid (2010) 20(5):535-44. doi:10.1089/ thy. 2009.0447

49. Kao JJ. The NF-kappaB inhibitor pyrrolidine dithiocarbamate blocks IL-1beta induced hyaluronan synthase 1 (HAS1) mRNA transcription, pointing at NFkappaB dependence of the gene HAS1. Exp Gerontol (2006) 41(6):641-7. doi:10.1016/j.exger.2006.04.003

50. Stuhlmeier KM. Effects of leflunomide on hyaluronan synthases (HAS): NFkappa B-independent suppression of IL-1-induced HAS1 transcription by leflunomide. J Immunol (2005) 174(11):7376-82. doi:10.4049/jimmunol.174. 11.7376

51. Stuhlmeier KM, Pollaschek C. Glucocorticoids inhibit induced and noninduced mRNA accumulation of genes encoding hyaluronan synthases (HAS): hydrocortisone inhibits HAS1 activation by blocking the p38 mitogenactivated protein kinase signalling pathway. Rheumatology (Oxford) (2004) 43(2):164-9. doi:10.1093/rheumatology/keh014

52. Tsui S, Fernando R, Chen B, Smith TJ. Divergent Spl protein levels may underlie differential expression of UDP-glucose dehydrogenase by fibroblasts: role in susceptibility to orbital Graves disease. J Biol Chem (2011) 286(27):24487-99. doi:10.1074/jbc.M111.241166

53. Chen L, Neville RD, Michael DR, Martin J, Luo DD, Thomas DW, et al. Identification and analysis of the human hyaluronan synthase 1 gene promoter reveals Smad3- and Sp3-mediated transcriptional induction. Matrix Biol (2012) 31 (78):373-9. doi:10.1016/j.matbio.2012.10.002

54. Rauhala L, Hämäläinen L, Salonen P, Bart G, Tammi M, Pasonen-Seppänen $\mathrm{S}$, et al. Low dose ultraviolet B irradiation increases hyaluronan synthesis in epidermal keratinocytes via sequential induction of hyaluronan synthases Has1-3 mediated by p38 and Ca2+/calmodulin-dependent protein kinase II (CaMKII) signaling. J Biol Chem (2013) 288(25):17999-8012. doi:10.1074/jbc. M113.472530

55. Decleves AE, Caron N, Voisin V, Legrand A, Bouby N, Kultti A, et al. Synthesis and fragmentation of hyaluronan in renal ischaemia. Nephrol Dial Transplant (2012) 27(10):3771-81. doi:10.1093/ndt/gfs098

56. Eldridge L, Moldobaeva A, Wagner EM. Increased hyaluronan fragmentation during pulmonary ischemia. Am J Physiol Lung Cell Mol Physiol (2011) 301(5):L782-8. doi:10.1152/ajplung.00079.2011

57. Zhuang Y, Yin Q. Peroxisome proliferator-activated receptor gamma agonists attenuate hyperglycaemia-induced hyaluronan secretion in vascular smooth muscle cells by inhibiting PKCbeta2. Cell Biochem Biophys (2013) 67(2):583-90. doi:10.1007/s12013-013-9545-4

58. Shimabukuro Y, Ueda M, Ichikawa T, Terashi Y, Yamada S, Kusumoto Y, et al. Fibroblast growth factor-2 stimulates hyaluronan production by human dental pulp cells. J Endod (2005) 31(11):805-8. doi:10.1097/01.don.0000158242. 44155.49

59. Shimabukuro Y, Ichikawa T, Takayama S, Yamada S, Takedachi M, Terakura $\mathrm{M}$, et al. Fibroblast growth factor-2 regulates the synthesis of hyaluronan by human periodontal ligament cells. J Cell Physiol (2005) 203(3):557-63. doi:10.1002/jcp. 20256

60. Kuroda K, Utani A, Hamasaki Y, Shinkai H. Up-regulation of putative hyaluronan synthase mRNA by basic fibroblast growth factor and insulin-like growth factor-1 in human skin fibroblasts. J Dermatol Sci (2001) 26(2):156-60. doi:10.1016/S0923-1811(00)00155-9

61. Kaback LA, Smith TJ. Expression of hyaluronan synthase messenger ribonucleic acids and their induction by interleukin-1beta in human orbital fibroblasts: potential insight into the molecular pathogenesis of thyroid-associated ophthalmopathy. J Clin Endocrinol Metab (1999) 84(11):4079-84. doi:10.1210/ jcem.84.11.6111

62. Li L, Asteriou T, Bernert B, Heldin CH, Heldin P. Growth factor regulation of hyaluronan synthesis and degradation in human dermal fibroblasts: importance of hyaluronan for the mitogenic response of PDGF-BB. Biochem J (2007) 404(2):327-36. doi:10.1042/BJ20061757

63. Guo N, Baglole CJ, O'Loughlin CW, Feldon SE, Phipps RP. Mast cell-derived prostaglandin D2 controls hyaluronan synthesis in human orbital fibroblasts via DP1 activation: implications for thyroid eye disease. J Biol Chem (2010) 285(21):15794-804. doi:10.1074/jbc.M109.074534

64. Stuhlmeier KM. Prostaglandin E2: a potent activator of hyaluronan synthase 1 in type-B-synoviocytes. Biochim Biophys Acta (2007) 1770(1):121-9. doi:10.1016/j.bbagen.2006.07.001

65. Sugiyama Y, Shimada A, Sayo T, Sakai S, Inoue S. Putative hyaluronan synthase mRNA are expressed in mouse skin and TGF-beta upregulates their expression in cultured human skin cells. J Invest Dermatol (1998) 110(2):116-21. doi:10. 1046/j.1523-1747.1998.00093.x

66. Freudenberger T, Rock K, Dai G, Dorn S, Mayer P, Heim HK, et al. Estradiol inhibits hyaluronic acid synthase 1 expression in human vascular smooth muscle cells. Basic Res Cardiol (2011) 106(6):1099-109. doi:10.1007/s00395-0110217-5

67. Vigetti D, Rizzi M, Viola M, Karousou E, Genasetti A, Clerici M, et al. The effects of 4-methylumbelliferone on hyaluronan synthesis, MMP2 activity, proliferation, and motility of human aortic smooth muscle cells. Glycobiology (2009) 19(5):537-46. doi:10.1093/glycob/cwp022

68. Kawakami M, Suzuki K, Matsuki Y, Ishizuka T, Hidaka T, Konishi T, et al. Hyaluronan production in human rheumatoid fibroblastic synovial lining cells is increased by interleukin 1 beta but inhibited by transforming growth factor beta 1. Ann Rheum Dis (1998) 57(10):602-5. doi:10.1136/ard.57.10.602

69. Goentzel BJ, Weigel PH, Steinberg RA. Recombinant human hyaluronan synthase 3 is phosphorylated in mammalian cells. Biochem J (2006) 396(2):347-54. doi:10.1042/BJ20051782

70. Karousou E, Kamiryo M, Skandalis SS, Ruusala A, Asteriou T, Passi A, et al. The activity of hyaluronan synthase 2 is regulated by dimerization and ubiquitination. J Biol Chem (2010) 285(31):23647-54. doi:10.1074/jbc.M110.127050

71. Vigetti D, Deleonibus S, Moretto P, Karousou E, Viola M, Bartolini B, et al. Role of UDP-N-acetylglucosamine (GlcNAc) and O-glcnacylation of hyaluronan synthase 2 in the control of chondroitin sulfate and hyaluronan synthesis. J Biol Chem (2012) 287(42):35544-55. doi:10.1074/jbc.M112.402347

72. Vigetti D, Clerici M, Deleonibus S, Karousou E, Viola M, Moretto P, et al. Hyaluronan synthesis is inhibited by adenosine monophosphate-activated protein kinase through the regulation of HAS2 activity in human aortic smooth muscle cells. J Biol Chem (2011) 286(10):7917-24. doi:10.1074/jbc.M110. 193656

73. Ghosh A, Kuppusamy H, Pilarski LM. Aberrant splice variants of HAS1 (Hyaluronan Synthase 1) multimerize with and modulate normally spliced HAS1 protein: a potential mechanism promoting human cancer. J Biol Chem (2009) 284(28):18840-50. doi:10.1074/jbc.M109.013813

74. Pummill PE, DeAngelis PL. Alteration of polysaccharide size distribution of a vertebrate hyaluronan synthase by mutation. J Biol Chem (2003) 278(22):19808-14. doi:10.1074/jbc.M301097200

75. Pummill PE, Achyuthan AM, DeAngelis PL. Enzymological characterization of recombinant Xenopus DG42, a vertebrate hyaluronan synthase. J Biol Chem (1998) 273(9):4976-81. doi:10.1074/jbc.273.9.4976

76. Brinck J, Heldin P. Expression of recombinant hyaluronan synthase (HAS) isoforms in CHO cells reduces cell migration and cell surface CD44. Exp Cell Res (1999) 252(2):342-51. doi:10.1006/excr.1999.4645

77. Wilkinson TS, Bressler SL, Evanko SP, Braun KR, Wight TN. Overexpression of hyaluronan synthases alters vascular smooth muscle cell phenotype and promotes monocyte adhesion. J Cell Physiol (2006) 206(2):378-85. doi:10.1002/jcp. 20468

78. Müllegger J, Rustom A, Kreil G, Gerdes HH, Lepperdinger G. 'Piggy-back' transport of Xenopus hyaluronan synthase (XHAS1) via the secretory pathway to the plasma membrane. Biol Chem (2003) 384(1):175-82. doi:10.1515/BC.2003.019

79. Rilla K, Siiskonen H, Spicer AP, Hyttinen JM, Tammi MI, Tammi RH. Plasma membrane residence of hyaluronan synthase is coupled to its enzymatic activity. J Biol Chem (2005) 280(36):31890-7. doi:10.1074/jbc.M504736200

80. Spicer AP, Nguyen TK. Mammalian hyaluronan synthases: investigation of functional relationships in vivo. Biochem Soc Trans (1999) 27(2):109-15.

81. Rilla K, Tiihonen R, Kultti A, Tammi M, Tammi R. Pericellular hyaluronan coat visualized in live cells with a fluorescent probe is scaffolded by plasma membrane protrusions. J Histochem Cytochem (2008) 56(10):901-10. doi:10.1369/jhc.2008.951665

82. Kanomata N, Yokose T, Kamijo T, Yonou H, Hasebe T, Itano N, et al. Hyaluronan synthase expression in pleural malignant mesotheliomas. Virchows Arch (2005) 446(3):246-50. doi:10.1007/s00428-004-1197-8

83. Nykopp TK, Rilla K, Sironen R, Tammi MI, Tammi RH, Hämäläinen K, et al. Expression of hyaluronan synthases (HAS1-3) and hyaluronidases (HYAL1-2) in serous ovarian carcinomas: inverse correlation between HYAL1 and hyaluronan content. BMC Cancer (2009) 9:143. doi:10.1186/1471-2407-9-143

84. Nykopp TK, Rilla K, Tammi MI, Tammi RH, Sironen R, Hämäläinen K, et al. Hyaluronan synthases (HAS1-3) and hyaluronidases (HYAL1-2) in the accumulation of hyaluronan in endometrioid endometrial carcinoma. BMC Cancer (2010) 10:512. doi:10.1186/1471-2407-10-512 
85. Siiskonen H, Poukka M, Tyynelä-Korhonen K, Sironen R, Pasonen-Seppänen $\mathrm{S}$. Inverse expression of hyaluronidase 2 and hyaluronan synthases 1-3 is associated with reduced hyaluronan content in malignant cutaneous melanoma. BMC Cancer (2013) 13:181. doi:10.1186/1471-2407-13-181

86. Raheem KA, Marei WF, Mifsud K, Khalid M, Wathes DC, Fouladi-Nashta AA. Regulation of the hyaluronan system in ovine endometrium by ovarian steroids. Reproduction (2013) 145(5):491-504. doi:10.1530/REP-13-0001

87. Siponen M, Kullaa A, Nieminen P, Salo T, Pasonen-Seppänen S. Altered expression of hyaluronan, HAS1-2, and HYAL1-2 in oral lichen planus. J Oral Pathol Med (2014). doi:10.1111/jop.12294

88. Vigetti D, Deleonibus S, Moretto P, Bowen T, Fischer JW, Grandoch M, et al. Natural antisense transcript for hyaluronan synthase 2 (HAS2-AS1) induces transcription of HAS2 via protein O-GlcNAcylation. J Biol Chem (2014) 289(42):28816-26. doi:10.1074/jbc.M114.597401

89. Magee C, Nurminskaya M, Linsenmayer TF. UDP-glucose pyrophosphorylase: up-regulation in hypertrophic cartilage and role in hyaluronan synthesis. Biochem J (2001) 360(Pt 3):667-74. doi:10.1042/0264-6021:3600667

90. Vigetti D, Ori M, Viola M, Genasetti A, Karousou E, Rizzi M, et al. Molecular cloning and characterization of UDP-glucose dehydrogenase from the amphibian Xenopus laevis and its involvement in hyaluronan synthesis. J Biol Chem (2006) 281(12):8254-63. doi:10.1074/jbc.M508516200

91. Jokela TA, Jauhiainen M, Auriola S, Kauhanen M, Tiihonen R, Tammi MI, et al. Mannose inhibits hyaluronan synthesis by down-regulation of the cellular pool of UDP-N-acetylhexosamines. J Biol Chem (2008) 283(12):7666-73. doi:10.1074/jbc.M706001200

92. Petrey AC, de la Motte CA. Hyaluronan, a crucial regulator of inflammation. Front Immunol (2014) 5:101. doi:10.3389/fimmu.2014.00101

93. Stern R, Asari AA, Sugahara KN. Hyaluronan fragments: an information-rich system. Eur J Cell Biol (2006) 85(8):699-715. doi:10.1016/j.ejcb.2006.05.009

94. Taylor KR, Yamasaki K, Radek KA, Di Nardo A, Goodarzi H, Golenbock D, et al. Recognition of hyaluronan released in sterile injury involves a unique receptor complex dependent on Toll-like receptor 4, CD44, and MD-2. J Biol Chem (2007) 282(25):18265-75. doi:10.1074/jbc.M606352200

95. Termeer C, Benedix F, Sleeman J, Fieber C, Voith U, Ahrens T, et al. Oligosaccharides of hyaluronan activate dendritic cells via toll-like receptor 4. J Exp Med (2002) 195(1):99-111. doi:10.1084/jem.20001858

96. Voelcker V, Gebhardt C, Averbeck M, Saalbach A, Wolf V, Weih F, et al. Hyaluronan fragments induce cytokine and metalloprotease upregulation in human melanoma cells in part by signalling via TLR4. Exp Dermatol (2008) 17(2):100-7. doi:10.1111/j.1600-0625.2007.00638.x

97. Hyc A, Osiecka-Iwan A, Niderla-Bielinska J, Jankowska-Steifer E, Moskalewski S. Pro- and anti-inflammatory cytokines increase hyaluronan production by rat synovial membrane in vitro. Int J Mol Med (2009) 24(4):579-85. doi:10.3892/ijmm_00000268

98. Fischer JW, Schror K. Regulation of hyaluronan synthesis by vasodilatory prostaglandins. Implications for atherosclerosis. Thromb Haemost (2007) 98(2):287-95. doi:10.1160/TH07-02-0155

99. van den Boom M, Sarbia M, von Wnuck Lipinski K, Mann P, Meyer-Kirchrath J, Rauch BH, et al. Differential regulation of hyaluronic acid synthase isoforms in human saphenous vein smooth muscle cells: possible implications for vein graft stenosis. Circ Res (2006) 98(1):36-44. doi:10.1161/01.RES.0000199263. 67107.c0

100. Marzoll A, Nagy N, Wordehoff L, Dai G, Fries S, Lindner V, et al. Cyclooxygenase inhibitors repress vascular hyaluronan-synthesis in murine atherosclerosis and neointimal thickening. J Cell Mol Med (2009) 13(9B):3713-9. doi:10.1111/j.1582-4934.2009.00736.x

101. David-Raoudi M, Deschrevel B, Leclercq S, Galera P, Boumediene K, Pujol JP. Chondroitin sulfate increases hyaluronan production by human synoviocytes through differential regulation of hyaluronan synthases: role of p38 and Akt. Arthritis Rheum (2009) 60(3):760-70. doi:10.1002/art.24302

102. Chang MY, Tanino Y, Vidova V, Kinsella MG, Chan CK, Johnson PY, et al. Reprint of: a rapid increase in macrophage-derived versican and hyaluronan in infectious lung disease. Matrix Biol (2014) 35:162-73. doi:10.1016/j.matbio. 2014.04.003

103. Gelse K, Ekici AB, Cipa F, Swoboda B, Carl HD, Olk A, et al. Molecular differentiation between osteophytic and articular cartilage - clues for a transient and permanent chondrocyte phenotype. Osteoarthritis Cartilage (2012) 20(2):162-71. doi:10.1016/j.joca.2011.12.004
104. Yoshida M, Sai S, Marumo K, Tanaka T, Itano N, Kimata K, et al. Expression analysis of three isoforms of hyaluronan synthase and hyaluronidase in the synovium of knees in osteoarthritis and rheumatoid arthritis by quantitative real-time reverse transcriptase polymerase chain reaction. Arthritis Res Ther (2004) 6(6):R514-20. doi:10.1186/ar1223

105. Kultti A, Rilla K, Tiihonen R, Spicer AP, Tammi RH, Tammi MI. Hyaluronan synthesis induces microvillus-like cell surface protrusions. J Biol Chem (2006) 281(23):15821-8. doi:10.1074/jbc.M512840200

106. Jokela TA, Lindgren A, Rilla K, Maytin E, Hascall VC, Tammi RH, et al. Induction of hyaluronan cables and monocyte adherence in epidermal keratinocytes. Connect Tissue Res (2008) 49(3):115-9. doi:10.1080/ 03008200802148439

107. Meran S, Martin J, Luo DD, Steadman R, Phillips A. Interleukin-1beta induces hyaluronan and CD44-dependent cell protrusions that facilitate fibroblastmonocyte binding. Am J Pathol (2013) 182(6):2223-40. doi:10.1016/j.ajpath. 2013.02.038

108. Engström-Laurent A, Hallgren R. Circulating hyaluronic acid levels vary with physical activity in healthy subjects and in rheumatoid arthritis patients. Relationship to synovitis mass and morning stiffness. Arthritis Rheum (1987) 30(12):1333-8. doi:10.1002/art.1780301203

109. Tanimoto K, Ohno S, Fujimoto K, Honda K, Ijuin C, Tanaka N, et al. Proinflammatory cytokines regulate the gene expression of hyaluronic acid synthetase in cultured rabbit synovial membrane cells. Connect Tissue Res (2001) 42(3):187-95. doi:10.3109/03008200109005649

110. Stuhlmeier KM. Hyaluronan production in synoviocytes as a consequence of viral infections: HAS1 activation by Epstein-Barr virus and synthetic doubleand single-stranded viral RNA analogs. J Biol Chem (2008) 283(24):16781-9. doi:10.1074/jbc.M801669200

111. Cheng G, Swaidani S, Sharma M, Lauer ME, Hascall VC, Aronica MA. Hyaluronan deposition and correlation with inflammation in a murine ovalbumin model of asthma. Matrix Biol (2011) 30(2):126-34. doi:10.1016/j.matbio.2010. 12.003

112. Cheng G, Swaidani S, Sharma M, Lauer ME, Hascall VC, Aronica MA. Correlation of hyaluronan deposition with infiltration of eosinophils and lymphocytes in a cockroach-induced murine model of asthma. Glycobiology (2013) 23(1):43-58. doi:10.1093/glycob/cws122

113. Zhang L, Bowen T, Grennan-Jones F, Paddon C, Giles P, Webber J, et al. Thyrotropin receptor activation increases hyaluronan production in preadipocyte fibroblasts: contributory role in hyaluronan accumulation in thyroid dysfunction. J Biol Chem (2009) 284(39):26447-55. doi:10.1074/jbc. M109.003616

114. Yabushita H, Noguchi M, Kishida T, Fusano K, Noguchi Y, Itano N, et al. Hyaluronan synthase expression in ovarian cancer. Oncol Rep (2004) 12(4):739-43. doi:10.3892/or.12.4.739

115. Weiss I, Trope CG, Reich R, Davidson B. Hyaluronan synthase and hyaluronidase expression in serous ovarian carcinoma is related to anatomic site and chemotherapy exposure. Int J Mol Sci (2012) 13(10):12925-38. doi:10.3390/ijms131012925

116. Yamada Y, Itano N, Narimatsu H, Kudo T, Morozumi K, Hirohashi S, et al. Elevated transcript level of hyaluronan synthasel gene correlates with poor prognosis of human colon cancer. Clin Exp Metastasis (2004) 21(1):57-63. doi:10.1023/B:CLIN.0000017203.71293.e0

117. Kramer MW, Escudero DO, Lokeshwar SD, Golshani R, Ekwenna OO, Acosta $\mathrm{K}$, et al. Association of hyaluronic acid family members (HAS1, HAS2, and HYAL-1) with bladder cancer diagnosis and prognosis. Cancer (2011) 117(6):1197-209. doi:10.1002/cncr.25565

118. Golshani R, Lopez L, Estrella V, Kramer M, Iida N, Lokeshwar VB. Hyaluronic acid synthase-1 expression regulates bladder cancer growth, invasion, and angiogenesis through CD44. Cancer Res (2008) 68(2):483-91. doi:10.1158/ 0008-5472.CAN-07-2140

119. Auvinen P, Tammi R, Parkkinen J, Tammi M, Ågren U, Johansson R, et al. Hyaluronan in peritumoral stroma and malignant cells associates with breast cancer spreading and predicts survival. Am J Pathol (2000) 156(2):529-36. doi:10.1016/S0002-9440(10)64757-8

120. Auvinen P, Tammi R, Kosma VM, Sironen R, Soini Y, Mannermaa A, et al. Increased hyaluronan content and stromal cell CD44 associate with HER2 positivity and poor prognosis in human breast cancer. Int J Cancer (2013) 132(3):531-9. doi:10.1002/ijc.27707 
121. Karjalainen JM, Tammi RH, Tammi MI, Eskelinen MJ, Ågren UM, Parkkinen JJ, et al. Reduced level of CD44 and hyaluronan associated with unfavorable prognosis in clinical stage I cutaneous melanoma. Am J Pathol (2000) 157(3):957-65. doi:10.1016/S0002-9440(10)64608-1

Conflict of Interest Statement: The authors declare that the research was conducted in the absence of any commercial or financial relationships that could be construed as a potential conflict of interest.

Received: 08 December 2014; accepted: 22 January 2015; published online: 05 February 2015.
Citation: Siiskonen H, Oikari S, Pasonen-Seppänen S and Rilla K (2015) Hyaluronan synthase 1: a mysterious enzyme with unexpected functions. Front. Immunol. 6:43. doi 10.3389/fimmu.2015.00043

This article was submitted to Inflammation, a section of the journal Frontiers in Immunology.

Copyright (C) 2015 Siiskonen, Oikari, Pasonen-Seppänen and Rilla. This is an openaccess article distributed under the terms of the Creative Commons Attribution License (CC BY). The use, distribution or reproduction in other forums is permitted, provided the original author(s) or licensor are credited and that the original publication in this journal is cited, in accordance with accepted academic practice. No use, distribution or reproduction is permitted which does not comply with these terms. 